\title{
MECHANISMS IN ENDOCRINOLOGY Clinical and pharmacogenetic aspects of the growth hormone receptor polymorphism
}

\author{
Cesar L Boguszewski', Edna J L Barbosa', Per-Arne Svensson ${ }^{2,3}$, Gudmundur Johannsson ${ }^{4}$ and \\ Camilla A M Glad ${ }^{2,4}$
}

${ }^{1}$ SEMPR, Endocrine Division, Department of Internal Medicine, Federal University of Parana, Curitiba, Brazil, ${ }^{2}$ Department of Molecular and Clinical Medicine, Institute of Medicine, The Sahlgrenska Academy, University of Gothenburg, Gothenburg, Sweden, ${ }^{3}$ Institute of Health and Care Sciences, The Sahlgrenska Academy, University of Gothenburg, Gothenburg, Sweden, and ${ }^{4}$ Department of Endocrinology, Sahlgrenska University Hospital and Department of Internal Medicine and Clinical Nutrition, Institute of Medicine, The Sahlgrenska Academy, University of Gothenburg, Gothenburg, Sweden

\author{
Correspondence \\ should be addressed \\ to C L Boguszewski \\ Email \\ clbogus@uol.com.br
}

\begin{abstract}
Pharmacogenetics aims to maximize the beneficial effects of a medical therapy by identifying genetic finger prints from responders and non-responders and, thereby improving safety and efficacy profile of the drug. Most subjects who are deficient in growth hormone (GHD) are candidates for recombinant human GH (rhGH) therapy. To date, it is well established that even after adjustments for several clinical variables, such as age, gender, body composition and the age at onset of the GHD, response to rhGH treatment is highly variable among individuals, part of which is believed to be due to genetic factors within the GH system. As the first genetic variant to potentially influence the individual response to $\mathrm{rhGH}$ therapy in children with growth disorders, polymorphism in the GH receptor (GHR) has attracted a great interest as a target for pharmacogenetics. Studies have been conducted to compare the functional and molecular effects of the full-length GHR ( $f l-G H R)$ isoform with the exon 3 deleted (d3-GHR) isoform in children and adults treated with rhGH therapy. Additionally, the impact of the GHR polymorphism has been investigated in relation to the clinical status and response to medical treatment in acromegaly, especially to the GHR antagonist drug pegvisomant. We have performed a narrative review of the studies performed to date on the association of GHR polymorphism with rhGH response in children and adults, and its potential influence in the medical management of acromegaly. In addition, data from studies on the general population and in other chronic diseases examining a role of this genetic variant in the regulation of growth and metabolism are summarized.
\end{abstract}

European Journal of

Endocrinology

(2017) 177, R309-R321

\section{The growth hormone receptor (GHR)}

Growth hormone (GH) exerts its biological effects by binding to the GH receptor (GHR). The GHR protein is positioned at the cell membrane of almost every cell in the human body and contains a 246 amino acids long extracellular (GH-binding) domain, a transmembrane domain and a 350 amino acids long intracellular (cytoplasmic) domain. In total, the GHR protein is composed of 638 residues (1). Binding of GH to the
GHR induces a series of subtle conformational events within a receptor homodimer, rather than a simple receptor dimerization, promoting a realignment of the two receptors both by relative rotation and by closer apposition just above the cell membrane (2). The parallel receptor transmembrane domains are converted into a rotated crossover orientation and the lower parts of the transmembrane helices are separated. GHR activation
() 2017 European Society of Endocrinology Printed in Great Britain
Published by Bioscientifica Ltd. 
results in the separation of the two associated janus kinase 2 (JAK2) and removes the inhibitory pseudokinase of one JAK2 from the kinase domain of the other JAK2 (and vice versa). This process brings the two kinase domains together for trans-activation and initiates tyrosine transphosphorylation of the GHR cytoplasmic domain and other substrates such as STAT5, which is the key transcription factor for most genomic actions of GH. In addition, as shown in Fig. 1, GH can also activate GHR-associated Src family kinases, independently of JAK2, acting via other intracellular pathways such as ERK and Jun (3).

The human GHR protein is encoded by the GHR gene, which is located on the proximal short arm of chromosome 5 (region p13.1-p12) $(4,5)$. The gene contains nine coding exons, which spans at least 87 kilobase pairs of

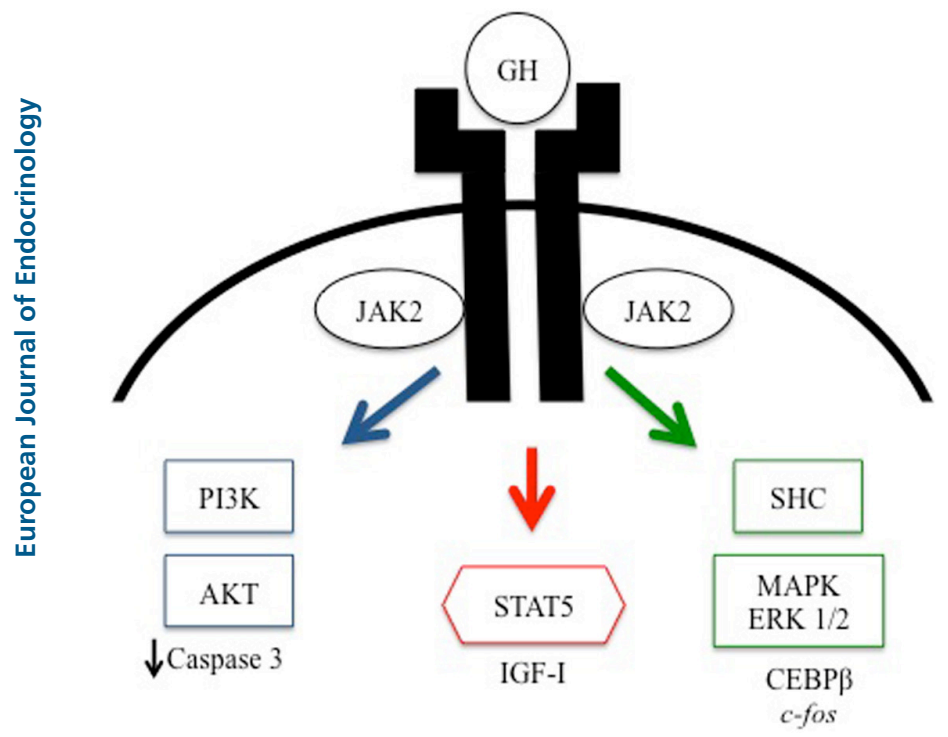

\section{Figure 1}

Schematic and simplified view of the GHR signaling cascade. Binding of GH to the GHR induces rotation of, and signal transduction through, the GHR leading to phosphorylation of the closely associated JAK2 protein. A series of transphosphorylation steps then leads to activation of signaling molecules such as STAT5, PI3K and SHC resulting in either increased or reduced transcription of a variety of GH-responsive genes such as IGF-I, CEBP $\beta$, Caspase 3 and more. AKT, serine/ threonine protein kinase; CEBP, CCAAT/enhancer binding protein; ERK1/2, extracellular-signal-regulated kinases; IGF, insulin-like growth factor; JAK, Janus kinase; MAPK, mitogenactivated protein kinases; $\mathrm{PI} 3 \mathrm{~K}$, phosphoinositide 3-kinases; SHC, Src homology 2 and 3 (SH2 and SH3) containing domains; STAT, signal transducers and activators of transcription. chromosome 5. Exon 2 encodes the final 11 base pairs of the $5^{\prime}$ untranslated region and the first amino acids of the extracellular domain (the signal sequence that is cleaved off from the mature GHR protein). Exons 3-7 encode the remaining large mass of the extracellular domain, exon 8 encodes the transmembrane domain and exons 9-10 encode the intracellular and 3' untranslated domains. In addition, the gene also contains several additional exons in the $5^{\prime}$ untranslated region $(4,5)$.

\section{Initial observations of the GHR exon 3 deleted/full-length polymorphism}

The first report of GHR cDNA clones with differences within the coding region came from Godowski et al. in 1989 (5). In one of these clones, the entire GHR exon 3 sequence was missing, giving rise to a GHR protein lacking 22 amino acids in the extracellular binding domain (Fig. 2). The resulting protein (d3-GHR) also contains an aspartic acid instead of an alanine residue at the exon 2-4 junction (6).

The initial studies investigating the exon 3 deletion generated a hypothesis that the d3-GHR was caused by an alternative splicing event, and the expression of the two isoforms were subsequently studied. Two independent studies reported on a tissue-specific expression pattern of the two isoforms, with the d3-GHR primarily expressed in the placental villi and amnion and the full-length receptor (fl-GHR) found exclusively in the chorion and decidua $(6,7)$. Another study found that both isoforms were expressed in 19 tissues, but the relative amounts differed among the sites (8). However, subsequent studies suggested that the expression pattern of the GHR isoforms was subject-specific and/or developmentally regulated, rather than tissue-specific $(9,10)$. Later in 1996, Stallings-Mann et al. (11) finally showed that the d3-GHR expression was not tissue-specific, neither developmentally regulated, but actually subject-specific and consequence of a polymorphism in the GHR gene that follows a simple Mendelian mode of inheritance. In 2000, Pantel et al. (12) shed some light on the origin of this polymorphism when they reported on the existence of two 99\% identical retroelements flanking exon 3. The retroelements are 251 base pairs long, located 577 base pairs upstream and 1821 base pairs downstream of exon 3 and underlies the creation of the d3-GHR through an early homologous recombination event, which has been passed on through generations. The resulting deletion involves not only the exon 3, but also parts of introns 2 and 3 . 
In humans, proteolytic cleavage in an undetermined site of the extracellular domain from both fl-GHR and d3-GHR variants gives arise to the GH-binding protein (13).

\section{Functional consequences of the GHR exon 3 deletion (d3-GHR)}

Several studies have investigated the consequences of the loss of amino acids 7-28 in the GHR protein in the d3-GHR variant, but to date the importance of this region is still not completely understood. This polymorphism has received major attention as the loss of an entire exon

A

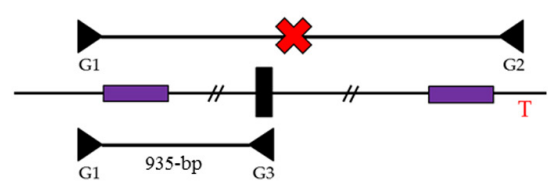

d3-GHR

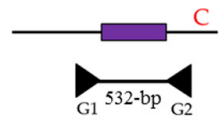

B

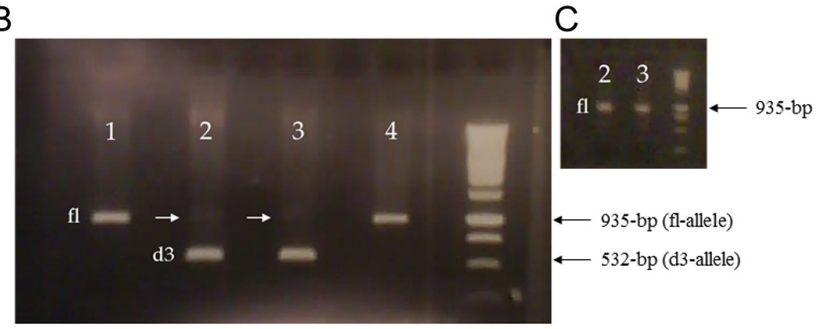

Figure 2

The GHR exon 3 deleted (d3-GHR)/full-length (fl-GHR) polymorphism. (A) Schematic view of the GHR exon 3 locus. Black boxes represent exon 3, purple boxes represent the LTR sequences flanking exon 3, arrows represent primers G1, G2 and G3 used for the conventional PCR genotyping assay and the red cross shows that the fl-GHR fragment is not produced using primers $\mathrm{G} 1$ and $\mathrm{G} 2$, due to the length of the fragment and competition over PCR reagents. Letters $\mathrm{C} / \mathrm{T}$ in red represents the respective rs6873545 alleles tagging the GHR d3/fl polymorphism. (B) Ethidium bromide-stained gel electrophoresis. Samples in lanes 1 and 4 are fl-homozygotes (one strong band of 935-bp amplicon). White arrows in lanes 2 and 3 highlight the difficulty in determining the presence of the 935-bp amplicon in some $d 3 / f \mid$ subjects, whereas the 532-bp amplicon (detecting the d3-allele) is clearly visible in these samples. (C) The same samples 2 and 3 from panel $B$ in a second round of PCR using only primers $\mathrm{G} 1$ and $\mathrm{G} 3$, resulting in clear amplification of the 935-bp amplicon (fl-allele). Primer sequence and positioning can be found at GenBank (accession no. AF155912). from one mRNA without affecting structure or function of the resultant protein is an unusual phenomenon. Even though the region appears to be conserved among GHR proteins in mammals, the d3-GHR isoform has been only found in humans and has not been demonstrated in other closely related proteins, such as the prolactin receptor (13).

The GH-binding capacities of the two GHR isoforms are similar $(6,14,15)$. Moreover, when modeled by crystallography, the amino acids encoded by exon 3 of the GHR gene do not appear to interact in a significant manner with GH (16). In 2004, Dos Santos et al. (17) transfected 293 HEK fibroblasts with vectors expressing both GHR isoforms, either alone or simultaneously, and quantified signal transduction by induction of the firefly luciferace gene coupled to the GH-responsive STAT5 promoter. They showed that transduction of GH signaling was approximately 30\% greater through d3-GHR homo- and heterodimers than through fl-GHR homodimers. This study is still the only one reporting on a functional difference between the two GHR isoforms in an experimental cell model.

\section{Effects of the d3-GHR polymorphism on height, metabolism and longevity in the general population}

In the general population, there is considerable variation in the frequency of the d3-GHR polymorphism between ethnic groups, and its frequency can be as high as 50\% considering heterozygous and homozygous individuals. The d3-GHR polymorphism has been studied in some populations representing subjects with a normal, undisturbed GH secretion. In 2003, Pantel et al. (18) concluded that a single copy of either the d3-GHR or the fl-GHR was sufficient for normal growth, and this was later confirmed in a large study by Lettre et al. (19), where the d3-GHR polymorphism was shown to have no influence in the adult height variation. A more recent Brazilian study found that the d3-GHR genotype was negatively associated with birth size, but it was not associated with adult height or weight, plasma IGF-I, metabolic phenotype or any marker of increased cardiovascular risk in adults (20).

In 2007, Strawbridge et al. (21) investigated the polymorphism in a Swedish set of 158 subjects with normal glucose tolerance (NGT), 116 subjects with impaired glucose tolerance (IGT) and 194 subjects with type 2 diabetes mellitus (T2DM). In this study, there was a significantly lower frequency of d3-GHR carriers among the T2DM group. On the other hand, among the T2DM 
subjects, the carriers of the d3-GHR had higher serum IGF-I levels, body mass index (BMI) and exhibited a metabolic profile characterized by higher C-reactive protein (CRP) and a tendency toward an unfavorable lipid profile.

Jensen et al. (22) investigated 115 healthy adolescents divided into those born small for gestational age (SGA) and appropriate for gestational age (AGA) with or without intrauterine growth restriction. They observed that the d3-GHR polymorphism was associated with a decreased third-trimester fetal growth velocity in SGA subjects. Interestingly, there was a significantly higher prevalence of the d3-GHR polymorphism among subjects born SGA with verified intrauterine growth restriction. In contrast, in the same study, carriers of the d3-GHR showed an increased growth velocity postnatally compared to fl-GHR homozygotes. In another study including two large, normal white European birth cohorts, the fl/fl genotype was associated with larger placental weight and birth weight SDS (23). In an Italian study, the d3/d3 GHR genotype was found twice as frequent in appropriate and large for gestational age than in small for gestational age newborns, leading the authors to exclude the d3-GHR polymorphism as a possible genetic factor for pregnancies with large babies (24).

In a cohort of 142 healthy Caucasian children and adolescents studied during puberty, an association between the presence of at least one d3-GHR allele with higher insulin secretion, disposition index and triglyceride levels was shown, suggesting a potential role for the d3-GHR polymorphism in pancreatic beta-cell compensatory capacity (25). In another study involving 618 healthy boys, an association between d3-GHR homozygosity and smaller birth size and earlier age at pubertal onset has been demonstrated, suggesting an impact of this polymorphism on prenatal growth and gonadal development in boys (26). In a subgroup of The Swedish Obese Subjects (SOS) reference study, consisting of 1135 subjects $(46.2 \%$ men), with an average age of 49.5 years, we found that subjects homozygous for the d3-GHR weighed approximately $4 \mathrm{~kg}$ more and had larger waist-to-hip ratio, larger waist circumference and more fat-free mass estimated from total body potassium than grouped $\mathrm{d} 3 / \mathrm{fl}$ and $\mathrm{fl} / \mathrm{fl}$ subjects, indicating an effect of the d3-GHR genetic variant on body composition (27). In contrast, a study conducted in China showed a significant effect of the d3-GHR polymorphism on BMI and metabolic parameters in a group of children with obesity, with a protective role of d3-GHR on the development of metabolic syndrome in association with increased insulin sensitivity (28).
More recently, a study performed in 841 individuals from four independent cohorts of long-lived individuals (Longevity Genes Project, Old Order Amish, Cardiovascular Health Study, and French Long-Lived Study) found a linear increased prevalence of d3-GHR homozygosity with age and showed that the presence of d3-GHR allele positively affected male longevity. In the multivariate regression analysis, the presence of $\mathrm{d} 3 / \mathrm{d} 3$ genotype added approximately 10 years to life span (29).

In summary, the presence of d3-GHR genotype does not seem to have a major impact on adult height in the general population, but it might exert some influence on body composition and metabolic parameters both in children and adults and might influence male life span.

\section{GHR polymorphism in short children}

Several studies have examined the involvement of GHR polymorphism in the clinical picture and in response to rhGH therapy in different groups of GHD (Table 1) and non-GHD children (Table 2) with short stature. As expected from genetic studies with numerous limitations, such as small sample size, distinct populations and high degree of heterogeneity, the results have been fairly conflicting.

Wassenaar et al. (30) conducted a systematic review and meta-analysis of 15 studies published between 2004 and 2008, with a range of 28-240 patients included in the series, aiming at assessing the effects of d3-GHR on baseline height and the first year's growth response to rhGH treatment in prepubertal short GHD children (7 studies) and non-GHD children (6 studies in small for gestational age (SGA), 3 studies in idiopathic short stature (ISS) and 2 studies in Turner syndrome). The meta-analysis showed that d3-GHR was associated with increased baseline height in GHD prepubertal children with short stature, but not in non-GHD children. In addition, growth response during the first year of rhGH therapy, expressed both as height SDS gain and as growth velocity, was significantly increased in prepubertal non-GHD and GHD short children bearing the d3-GHR genotype in comparison with the fl-GHR genotype. The meta-analysis found that the presence of d3-GHR allele stimulated growth velocity by an additional effect of approximately $0.5 \mathrm{~cm}$ during the first year of rhGH treatment, and such effect was more pronounced at lower rhGH doses and in children of higher age (30).

The methodological approach used by Wassenaar et al. (30) in their systematic review and meta-analysis has been criticized, as the model used to estimate 
Table 1 Effects of d3-GHR polymorphism on baseline height and growth velocity and height gain in response to recombinant growth hormone (rhGH) in short GH-deficient children.

\begin{tabular}{|c|c|c|c|c|c|c|c|}
\hline \multirow[b]{2}{*}{ Reference } & \multirow[b]{2}{*}{ n } & \multicolumn{4}{|c|}{ Genotypes, \% } & \multirow[b]{2}{*}{ Baseline height } & \multirow[b]{2}{*}{ Growth velocity and height gain } \\
\hline & & $\mathrm{fl}-\mathrm{fl}$ & d3-fl & d3-d3 & d3-carriers & & \\
\hline \multicolumn{8}{|c|}{ Systematic review and meta-analysis } \\
\hline (30) & $7(613) *$ & $43-55$ & $36-47$ & $3-13$ & $45-56$ & Increase & Increase \\
\hline (31) & $7(629) *$ & $43-55$ & NA & NA & $45-57$ & NA & Modest increase \\
\hline \multicolumn{8}{|l|}{ Cohorts } \\
\hline$(32)$ & 45 & 51.1 & NA & NA & 48.9 & No effect & Increase \\
\hline (33) & 111 & 67.6 & 18.9 & 13.5 & 32.4 & No effect & Increase \\
\hline (34) & 74 & 62.2 & 27 & 10.8 & 37.8 & No effect & $\begin{array}{l}\text { Increase first year } \\
\text { No effect second year }\end{array}$ \\
\hline$(35)$ & 67 & 64.2 & 29.9 & 5.9 & 35.8 & No effect & No effect \\
\hline (36) & 218 & 28.4 & 46.8 & 24.8 & 71.6 & No effect & No effect \\
\hline \multicolumn{8}{|c|}{ Open-label trial } \\
\hline (37) & 94 & 39.4 & 50 & 10.6 & 60.6 & No effect & $\begin{array}{l}\text { Dichotomous influence dependent } \\
\text { on peak GH level: lower peak } \\
\text { GH, worse growth }\end{array}$ \\
\hline & & & & & & & Higher peak GH, better growth \\
\hline
\end{tabular}

*Number of studies included in the meta-analysis, with the total number of children studied between parentheses NA, information not available.

treatment effect comparing d3-GHR carriers vs noncarriers assumed that the underlying inheritance is dominant (31). To overcome this and other potential biases, Renehan et al. (31) performed a systematic review including 12 studies and 1527 short children from any cause, using an established Bayesian inheritance modelfree approach to meta-analyze the data and quantify the effects of the d3/fl-GHR and d3-GHR genotypes on rhGH therapy response. Their primary outcome was the 1-year change in height SDS for the two genotypes.
They concluded that the inheritance of d3-GHR polymorphism is codominant, and this variant accounts for a modest increase in growth response in response to rhGH in children.

After the publication of the abovementioned systematic reviews and meta-analysis, some additional clinical studies were published demonstrating the low uniformity in the data. In three distinct cohorts of GHD short children, two from China $(32,33)$ and one from Greece (34), the presence of at least one d3-GHR allele was

Table 2 Effects of d3-GHR polymorphism on baseline height and growth velocity and height gain in response to recombinant growth hormone (rhGH) in non-GH-deficient short children.

\begin{tabular}{|c|c|c|c|c|c|c|c|}
\hline \multirow[b]{2}{*}{ Reference } & \multirow{2}{*}{$\begin{array}{l}\text { Clinical } \\
\text { condition }(n)\end{array}$} & \multicolumn{4}{|c|}{ Genotypes, \% } & \multirow{2}{*}{$\begin{array}{c}\text { Baseline } \\
\text { height }\end{array}$} & \multirow{2}{*}{$\begin{array}{l}\text { Growth velocity and height } \\
\text { gain }\end{array}$} \\
\hline & & $\mathrm{fl}-\mathrm{fl}$ & d3-fl & d3-d3 & d3-carriers & & \\
\hline \multicolumn{8}{|c|}{ Systematic review and meta-analysis } \\
\hline \multirow[t]{3}{*}{ (30) } & 6 SGA (712)* & $44-60$ & $27-47$ & $9-21$ & $40-55$ & No effect ${ }^{\S}$ & Increase ${ }^{\S}$ \\
\hline & 3 ISS (264)* & $43-71$ & $25-40$ & $4-17$ & $29-57$ & & \\
\hline & 2 TS $(101) *$ & $50-51$ & $28-36$ & $14-21$ & $49-50$ & & \\
\hline \multirow[t]{2}{*}{ (31) } & $\begin{array}{l}8 \text { SGA + ISS } \\
(708) *\end{array}$ & $43-62$ & NA & NA & $38-57$ & No effect ${ }^{\S}$ & Modest increase ${ }^{\S}$ \\
\hline & 3 TS $(190) *$ & $50-64$ & NA & NA & $36-50$ & & \\
\hline \multicolumn{8}{|l|}{ Cohorts } \\
\hline (38) & ISS (167) & 58.4 & 33.2 & 8.4 & 41.6 & No effect & No effect \\
\hline (39) & SGA (142) & 47.8 & 38 & 14.2 & 52.2 & No effect & $\begin{array}{l}\text { Increase in the first year } \\
\text { No effect in the second year }\end{array}$ \\
\hline$(40)$ & TS $(175) * *$ & 74.3 & 22.9 & 2.8 & 25.7 & No effect & No effect \\
\hline
\end{tabular}


associated with better growth velocity after 6 or 12 months of rhGH therapy, whereas in two other European series, one from Poland (35) and one from Turkey (36), this polymorphism had no influence on growth response in GHD short children.

Recently, the associations between d3-GHR and growth response to rhGH over 3 years in relation to severity of GHD were investigated in the PREDICT trials (37). The PREDICT Long-Term Follow-up of Predictive Markers study was an open-label trial involving prepubertal treatmentnaïve GHD children from 14 countries. Interestingly, the authors reported on a dichotomous influence of d3-GHR polymorphism on response to rhGH, dependent on peak GH level. d3-GHR carriers with lower peak GH exhibited lower growth than subjects with $\mathrm{fl} / \mathrm{fl}$ (median difference after 3 years $-3.3 \mathrm{~cm} ;-0.3 \mathrm{SDS})$. In contrast, d3-GHR carriers with higher peak GH had better growth $(+2.7 \mathrm{~cm} ;+0.2$ SDS), indicating that the influence of $\mathrm{d} 3 \mathrm{-GHR}$ on therapeutic response is modulated by the severity of GHD (37).

In relation to non-GHD children, our group has longitudinally followed 167 prepubertal children with ISS who were treated with rhGH and had growth and metabolic outcomes evaluated at birth $(n=166)$, after one year of treatment $(n=59)$ and at adult height $(n=145)$. In our study, GHR genotypes did not have an impact on growth and IGF-I response after one year of GH treatment and could not explain the growth response to treatment, differences in height SDS, height gain or difference in height to midparental height SDS at adult height (38). Another prospective multicenter study in non-GHD children was performed in Germany with 142 short prepubertal children born SGA, who received rhGH in a mean dose of $0.3 \mathrm{mg} / \mathrm{kg} /$ week (39). This trial showed a better treatment response in the d3-GHR carriers only after the first treatment year (both for height SDS and height velocity), with the differences between the genotypes groups disappearing after the second year of rhGH therapy. In girls with Turner syndrome, a study conducted in South Korea in a group of 175 patients (115 treated with rhGH remained prepubertal after the end of follow-up and were included in the final analysis of rhGH effects) found a similar distribution of the d3-GHR genotype in patients and in controls, without a significant impact of the GHR polymorphism on the efficacy of $\mathrm{rhGH}$ therapy (40). Finally, GHR polymorphism was shown to have no effect on the degree of growth delay among nonGHD children with Cushing disease (41).

In summary, the role of the d3-GHR polymorphism in growth and growth response to rhGH in children has been mostly studied in a limited and heterogeneous sample size, grouping d3-GHR homozygotes and heterozygotes, which could potentially mask the true effect of d3-GHR homozygosity in the outcomes. Moreover, many studies have used the conventional multiplex PCR assay for genotyping with the need for an additional round of PCR and an increased risk of over reporting d3/d3 genotypes. To overcome this problem, we suggest an international collaboration where the polymorphism would be easily studied using TaqMan SNP genotyping of the d3/fl tagSNP rs6873545, as described previously $(19,42)$ and further enlightened in Fig. 2, allowing a future extensive metaanalysis comparing the three genotype groups. In the current context, the use of the GHR polymorphism, alone or in association with other genetic variants within the GH-IGF-I axis, is of little value in prediction models to estimate the response to rhGH treatment in short children (43).

\section{GHR polymorphism in adults with growth hormone deficiency (GHD)}

In contrast with the pediatric studies, pharmacogenetic investigations related to the GH-IGF axis in adults with GHD are much more challenging due to the multiple end points of the rhGH therapy in this group of patients. Thus, few studies, most of them based on small numbers of observations, have tried to address the effect of d3-GHR polymorphism in hypopituitary adults with GHD and its potential implication with the response to rhGH therapy and, as expected, the designs have been heterogeneous and the results are conflicting (Table 3).

In a study of 313 consecutive GHD adults, we found that fl-GHR homozygotes individuals showed a better IGF-I response to rhGH than carriers of the d3-GHR after 1 week of therapy (44). We have also investigated a cohort of 124 adult GHD patients before and after 12 months of rhGH therapy, who were divided according to their genotypes into those bearing fl-GHR alleles (58\%) and those with at least one d3-GHR allele (30\% heterozygous and 12\% homozygous). Therapeutic outcomes examined in this study were changes on serum IGF-I levels and total body fat mass during therapy. In contrast to the previous study, we did not find any influence of d3-GHR in those parameters, neither at baseline nor in response to rhGH therapy (45). We believe, however, that our unique large short-term therapeutic response study (1 week) is a more optimal model for the purpose of better understanding the impact of the GHR genotype on GH sensitivity as long-term studies are more subjected to confounders such as dose titration and adherence to the treatment. 
Table 3 Studies investigating the effect of d3-GHR polymorphism on baseline characteristics and response to recombinant growth hormone therapy (rhGH) in adults with GH deficiency.

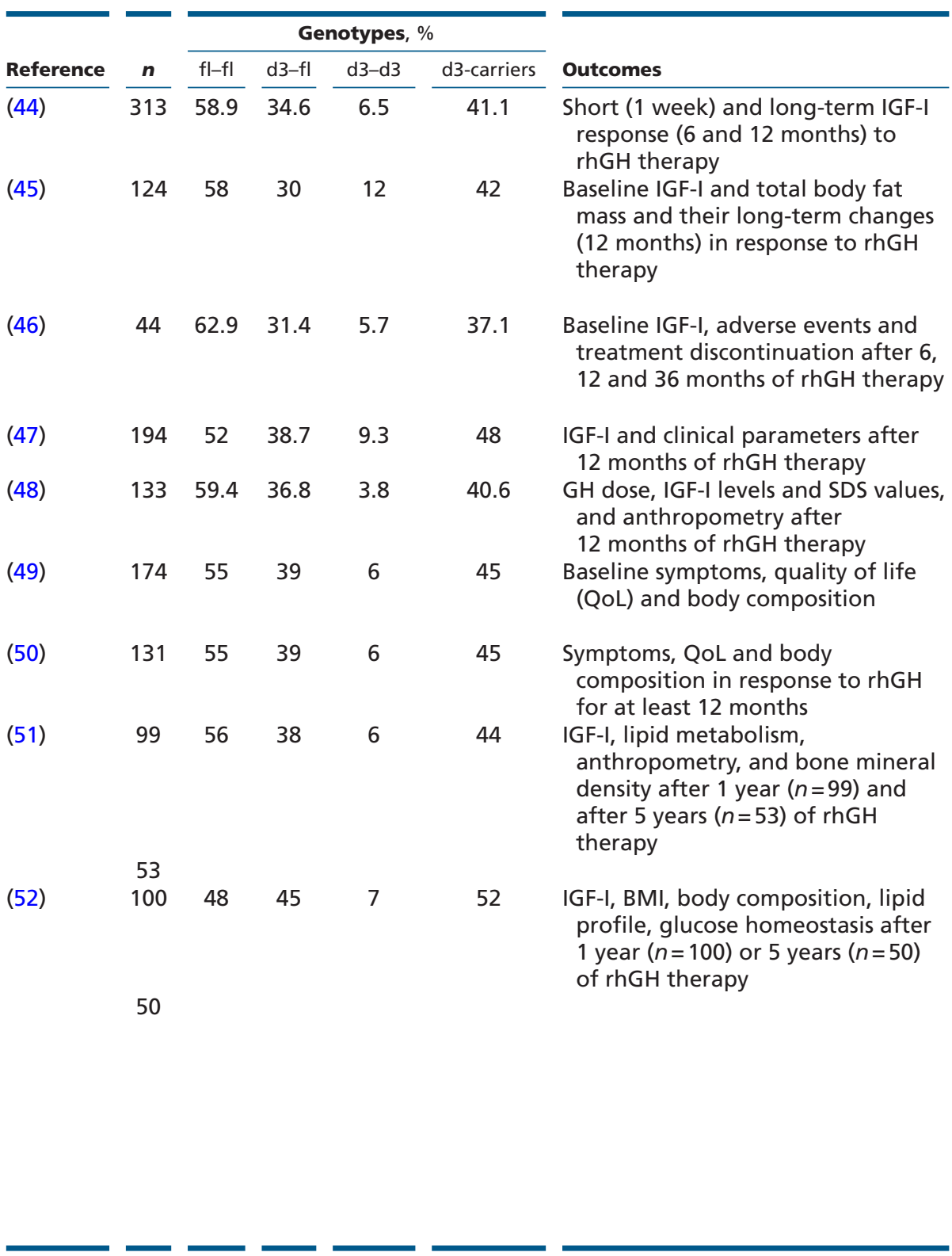

Main findings

Better IGF-I response at 1 week in the $\mathrm{fl}-\mathrm{fl}$ group that was associated with rhGH response at 6 and 12 months

No effect at baseline

No effect after therapy

No effect at baseline

No effect after therapy

Marginal increase in IGF-I levels in the d3-d3 group

$25 \%$ less rhGH to attain similar IGF-I levels in d3-carriers

Lower HADS (Hospital Anxiety and Depression Score) in d3-carriers, without clinical significance

No effect after therapy

At the same rhGH dose, d3-carriers had higher increase in IGF-I levels, lower reduction in total and LDL cholesterol and higher increase in HDL cholesterol

No effect after 5 years of therapy

No effect at baseline

Higher increase in HDL cholesterol and persistently higher fasting glucose in d3-carriers after 1 year Percentage of patients with impaired glucose tolerance decreased in $\mathrm{fl} / \mathrm{fl}$ while doubled in d3GHR patients, both after 1 and 5 years

Higher reduction in total and LDL cholesterol in d3 carriers after 5 years
In a cohort of 44 GHD adult patients followed in Spain, the d3-GHR allele was not related to baseline IGF-I levels, adverse events or treatment discontinuation (46). Another single-center study from the United Kingdom with a similar design was carried out with a larger cohort of $194 \mathrm{GHD}$ adults (52\% fl/fl, 38.7\% d3/fl and 9.3\% d3/d3 GHR) (47). In this study, a marginal increase in rhGH responsiveness at 12 months was observed only in d3-GHR homozygotes, but without a detectable difference in maintenance rhGH dose among genotypes, which led the authors to conclude that GHR polymorphism could not explain the marked heterogeneity of $\mathrm{GH}$ responsiveness in hypopituitary adults. In contrast, the German Pfizer International Metabolic Pharmacogenetics Study (KIMS) investigated 133 GHD adult patients also treated with rhGH for 12 months and found that d3-GHR carriers required approximately $25 \%$ less rhGH compared with the homozygous fl-carriers to attain similar IGF-I levels, suggesting an increased responsiveness to $\mathrm{rhGH}$ associated with d3-GHR polymorphism (48).

Adetunji et al. (49) examined whether the presence of d3-GHR could influence symptoms, quality of life (QoL) 
and body composition in a cohort of 174 untreated GHD adults $(55 \% \mathrm{fl} / \mathrm{fl}, 39 \% \mathrm{~d} 3 / \mathrm{fl}$ and $6 \% \mathrm{~d} 3 / \mathrm{d} 3 \mathrm{GHR})$. The only significant finding was a lower Hospital Anxiety and Depression Scores (HADS) in d3-GHR carriers compared to those bearing fl-GHR alleles, with no other differences in QoL parameters or body composition. The authors considered the difference in HADS between the two genotype groups in the asymptomatic GHD patients of little clinical significance as the scores were within the normal range and concluded that the GHR polymorphism had no impact on symptoms, QoL and body composition in untreated GHD adults. Using the same end points, they were also unable to demonstrate any influence of d3-GHR allele in the changes promoted by rhGH therapy in 131 GHD adults treated for more than 1 year (50).

In two studies, the impact of GHR polymorphism on IGF-I levels, metabolic parameters and body composition was examined both after 1 and 5 years of the start of rhGH therapy. In one of them, van der Klaauw et al. (51) followed 99 GHD patients (56\% fl/ fl, 38\% d3/fl and $6 \% \mathrm{~d} 3 / \mathrm{d} 3 \mathrm{GHR})$ treated with rhGH during 1 year and 53 treated during 5 years. At 1 year, patients bearing at least one d3-GHR allele showed a higher increase in IGF-I levels compared with those with two wild-type alleles, at an identical mean rhGH dose. In addition, d3-GHR carriers showed a lower reduction in total cholesterol and low-density lipoprotein cholesterol and higher increased in highdensity lipoprotein cholesterol after 1 year of rhGH treatment. At 5 years, however, these differential responses related to GHR genotypes were not observed. The second study investigated $100 \mathrm{GHD}$ adults (48\% fl/ $\mathrm{fl}, 45 \% \mathrm{~d} 3 / \mathrm{fl}$ and $7 \% \mathrm{~d} 3 / \mathrm{d} 3 \mathrm{GHR}$ ) treated during 1 year with rhGH and 50 treated during 5 years (52). At 1 year, d3-GHR carriers showed a more pronounced increase in high-density lipoprotein cholesterol compared to $\mathrm{fl} / \mathrm{fl}$ individuals, and fasting glucose remained significantly higher than the baseline values in d3-GHR individuals. Moreover, after both 1 and 5 years of rhGH therapy, the percentage of subjects with impaired glucose tolerance, which was similar in the groups at baseline, decreased in $\mathrm{fl} / \mathrm{fl}$ and doubled in $\mathrm{d} 3-\mathrm{GHR}$ patients. In this last group, a long-term significant reduction in total and low-density lipoprotein cholesterol was also observed.

From the aforementioned studies, there is little evidence that genetic variants of GHR play a relevant role in the clinical picture of untreated adults with GHD. Whether d3-GHR polymorphism exerts some influence on rhGH responsiveness in adult GHD is less clear, but if does, the magnitude of the effect is likely modest.

\section{GHR polymorphism in acromegaly}

Acromegaly is a chronic disease, usually caused by a GH-secreting pituitary adenoma, in which body tissues are exposed to excessive amounts of GH and IGF-I. Uncontrolled acromegaly is associated with increased mortality and several morbidities are commonly present, including IGT and T2DM, arterial hypertension, dyslipidemia, sleep apnea and malignancies (53, 54). Currently, acromegaly is treated by a combination of surgery, radiotherapy and three classes of drugs: dopamine-agonists (cabergoline), somatostatin analogs (octreotide, lanreotide, pasireotide) and GHR antagonists (pegvisomant). Serum GH and IGF-I measurements are employed for the diagnosis and, more importantly, for monitoring therapeutic response. In this respect, discordant GH and IGF-I values have been observed in up to $40 \%$ of the acromegaly patients, posing a challenge to the disease management (55). It has been questioned whether d3-GHR polymorphism could modulate GH sensitivity in acromegaly and, as a consequence, be responsible for the variability in the clinical presentation, hormone measurements and response to medical therapy, particularly to the GHR antagonist.

To date, findings from 17 studies, which are summarized in Table 4, have not been consistent and the importance of the d3-GHR polymorphism in acromegaly management remains highly controversial $(55,56,57$, $58,59,60,61,62,63,64,65,66,67,68,69,70,71)$. The number of patients with acromegaly examined varied from 19 to 186 among the reported series, with the prevalence of heterozygous d3/fl-GHR ranging from $13.3 \%$ to $57 \%$ and of d3-GHR homozygous from $0 \%$ to $22 \%$. In one study, d3-GHR carriers were younger (61) and in another they had higher systolic blood pressure, fasting insulin, HOMA-IR and BMI (64). In the remaining, no clear differences in clinical parameters were observed between patients with or without d3-GHR allele. In three series, the presence of at least one d3-GHR allele had a negative impact on acromegaly-related comorbidities, resulting in increased prevalence of diabetes (57), osteoarthritis, dolichocolon and adenomatous colonic polyps (60) or vertebral fractures (67). In contrast, one study found better glucose metabolism in d3-GHR carriers (63). Similarly, only 4 out of 17 studies reported on some influence of d3-GHR polymorphism in GH and IGF-I levels at diagnosis or during follow-up $(56,57,58,68)$, but with little evidence of its involvement on discordant hormone levels. Accordingly, despite the results of a Spanish multicenter study suggesting that d3-GHR 
Table 4 Studies investigating the effect of d3-GHR polymorphism on clinical and biochemical features and therapeutic outcomes in patients with acromegaly.

\begin{tabular}{|c|c|c|c|c|c|c|}
\hline \multirow[b]{2}{*}{ Reference } & \multirow[b]{2}{*}{$n$} & \multicolumn{4}{|c|}{ Genotypes, \% } & \multirow[b]{2}{*}{ Main findings } \\
\hline & & $\mathrm{fl}-\mathrm{fl}$ & d3-fl & d3-d3 & d3-carriers & \\
\hline (55) & 121 & 46.3 & 39.7 & 14 & 53.7 & $\begin{array}{l}\text { No influence on clinical and biochemical characteristics and treatment } \\
\text { outcomes }\end{array}$ \\
\hline (56) & 44 & 50 & 41 & 9 & 50 & Basal, mean and nadir GH on OGTT higher in fl-fl than in d3-carriers \\
\hline (57) & 148 & 46 & 32 & 22 & 54 & $\begin{array}{l}\text { Higher prevalence of diabetes, higher IGF-I levels and lower chance of IGF-I } \\
\text { normalization in d3-carriers }\end{array}$ \\
\hline (58) & 19 & 52.6 & 31.6 & 15.8 & 47.4 & $\begin{array}{l}\text { Lower dose and shorter treatment time with pegvisomant to normalize } \\
\text { IGF-I levels in d3-carriers }\end{array}$ \\
\hline (59) & 84 & 52.4 & 29.8 & 17.8 & 47.6 & Discordance between GH and IGF-I levels more frequent in d3-carriers \\
\hline$(60)$ & 86 & 59 & 34 & 7 & 41 & $\begin{array}{l}\text { Higher prevalence of osteoarthritis, adenomatous polyps and dolichocolon } \\
\text { in d3-carriers }\end{array}$ \\
\hline (61) & 105 & 51 & 30 & 19 & 49 & $\mathrm{~d} 3-\mathrm{d} 3$ were younger than $\mathrm{d} 3-\mathrm{fl}$ and $\mathrm{fl}-\mathrm{fl}$ \\
\hline$(62)$ & 44 & 41 & 57 & 2 & 59 & $\begin{array}{l}\text { Lower dose and shorter treatment time with pegvisomant to normalize } \\
\text { IGF-I levels in d3-carriers }\end{array}$ \\
\hline (63) & 76 & 55.3 & 35.5 & 9.2 & 44.7 & $\begin{array}{l}\text { Lower BMI, more frequent normal glucose tolerance in d3-carriers; } \\
\text { presence of d3-GHR was negative predictor of insulin levels on OGTT }\end{array}$ \\
\hline (64) & 35 & 54.3 & 31.4 & 14.3 & 45.7 & $\begin{array}{l}\text { Increased BMI, systolic blood pressure, fasting insulin and HOMA-IR in } \\
\text { d3-d3 group }\end{array}$ \\
\hline (65) & 127 & 53.5 & 32.3 & 14.2 & 46.5 & No effect on the response to pegvisomant treatment \\
\hline (66) & 112 & 52 & 38 & 10 & 48 & Higher risk of postsurgical recurrence in d3-carriers? \\
\hline (67) & 109 & 49.5 & 34 & 16.5 & 50.5 & Higher risk of vertebral fractures in d3-carriers \\
\hline (68) & 186 & 45 & 43 & 12 & 55 & $\begin{array}{l}\text { No influence on clinical and biochemical characteristics and treatment } \\
\text { outcomes }\end{array}$ \\
\hline (69) & 118 & 60.2 & 33.9 & 5.9 & 39.8 & No effect on clinical features and comorbidities \\
\hline (70) & 104 & 51 & 41.3 & 7.7 & 49 & No effect on the doses of pegvisomant during combined therapy with SRL \\
\hline (71) & 30 & 86.7 & 13.3 & 0 & 13.3 & Higher BMI in d3-carriers \\
\hline
\end{tabular}

predicts an improved response to GHR antagonist therapy in acromegaly (62), a recent systematic review showed no value of this polymorphism in predicting responsiveness to therapy (72). In summary, to date, there is no convincing and reproducible evidence for a significant impact of GHR polymorphism on the consequences of acromegaly and its management.

\section{GHR polymorphism in other chronic diseases}

The GH-IGF-I axis has been implicated in the pathophysiology of different chronic diseases, which has motivated some investigators to look for an association between GHR polymorphism and the clinical presentation in several pathological conditions. Two studies have examined such association in patients with Prader-Willi syndrome (PWS). In one study, seventy-four patients with a median age of 8.7 years were genotyped and their medical records were retrospectively reviewed. The distribution of alleles was not different from controls, but PWS carriers of the d3-GHR allele had significantly greater height SDS and higher IGF-I than non-carriers before starting rhGH therapy (73). In the second study, sixty-nine patients with PWS with an average age of
20.1 years were investigated, and again the frequency of GHR alleles was similar to that reported in the literature, with d3-GHR carriers showing a significant increase in BMI compared with those having the fl-GHR allele. In addition, among 12 PWS children treated with rhGH, a significant increase in growth rate (1.7 times) was noted in the presence of the d3-GHR allele (74).

A large controlled study was carried out in a cohort of 432 Chinese women with PCOS and 441 healthy control women (75). The authors found a higher frequency of the d3-GHR allele in PCOS patients, which was associated with plasma glucose measurements among PCOS patients and with increased waist and hip circumstance in healthy controls. In the Genetics, osteoARthritis and Progression (GARP) study, the prevalence of d3-GHR polymorphism was evaluated in patients with osteoarthritis and related to the clinical manifestations. The investigators found that in women, the d3-GHR polymorphism was associated with symptomatic osteoarthritis, especially at the hip site, independently of age and BMI (76).

In a cohort of patients with diabetes mellitus and coronary heart disease, Kucukhuseyin et al. (77) found no influence of the GHR polymorphism on either cardiovascular risk factors or serum GH, IGF-I and IGFBP-3 
levels. Accordingly, the Genetics of Kidneys in Diabetes (GoKinD) study did not show any association between GHR polymorphism and the development of diabetic nephropathy among type 1 diabetes patients (78).

\section{Summary and conclusions}

Almost 30 years have passed since the first reports of the d3-GHR isoform and still the exact mechanisms by which its functional effect is conveyed are incompletely understood. One single experimental study, which has not been consistently replicated, found a 30\% enhanced signal transduction in cells transfected with the d3-GHR, raising a large interest in using the GHR genotype to predict the response to rhGH in both children and adults (17). It is not possible, however, to estimate how a $30 \%$ improvement in in vitro GHR signal transduction would translate into clinical findings, as regulation of rhGH response in both children and adults is intriguingly complex and involves multiple factors other than the GHR signaling cascade. Epidemiologic studies have found associations of the d3-GHR isoform with longevity, anthropometric and metabolic parameters, in the general population. Previous systematic reviews and meta-analysis in GHD and nonGHD short children, as well as this narrative review including adults with GHD, show that the d3-GHR isoform may have a weak influence on the clinical phenotype and therapeutic response to rhGH, but data are heterogeneous and conflicting. However, it should be acknowledged that most studies involved a small number of observations, were not primarily designed to address the question of GHR genotype-phenotype relationships and, consequently, many issues on this association remain unsolved. In contrast, no influence of GHR polymorphism with major clinical significance has been found in acromegaly patients before or after treatment. For the next 30 years, we hope to see new experimental studies examining in more details the impact of d3-GHR isoform in relation to GH binding, GHR dimerization, rotation and signal transduction and, concomitantly, new clinical research on large series of patients specifically designed to clarify the physiological and pathological role of GHR polymorphism and its implication for pharmacogenetics.

\section{Declaration of interest}

The authors have no conflict of interest that could be perceived as prejudicing the impartiality of the research reported.

\section{Funding}

This study was sponsored by the Swedish Federal Government under the ALF agreement on medical training and research.

\section{References}

1 Leung DW, Spencer SA, Cachianes G, Hammonds RG, Collins C, Henzel WJ, Barnard R, Waters MJ \& Wood WI. Growth hormone receptor and serum binding protein: purification, cloning and expression. Nature 1987330 537-543. (doi:10.1038/330537a0)

2 Brooks AJ, Dai W, O’Mara ML, Abankwa D, Chhabra Y, Pelekanos RA, Gardon O, Tunny KA, Blucher KM, Morton CJ et al. Mechanism of activation of protein kinase JAK2 by the growth hormone receptor. Science 2014344 1249783. (doi:10.1126/science.1249783)

3 Waters MJ. The growth hormone receptor. Growth Hormone and IGF Research 201628 6-10. (doi:10.1016/j.ghir.2015.06.001)

4 Barton DE, Foellmer BE, Wood WI \& Francke U. Chromosome mapping of the growth hormone receptor gene in man and mouse. Cytogenetics and Cell Genetics 198950 137-141. (doi:10.1159/000132743)

5 Godowski PJ, Leung DW, Meacham LR, Galgani JP, Hellmiss R, Keret R, Rotwein PS, Parks JS, Laron Z \& Wood WI. Characterization of the human growth hormone receptor gene and demonstration of a partial gene deletion in two patients with Laron-type dwarfism. PNAS 198986 8083-8087. (doi:10.1073/pnas.86.20.8083)

6 Sobrier ML, Duquesnoy P, Duriez B, Amselem S \& Goossens M. Expression and binding properties of two isoforms of the human growth hormone receptor. FEBS Letters 1993319 16-20. (doi:10.1016/0014-5793(93)80028-S)

7 Urbanek M, MacLeod JN, Cooke NE \& Liebhaber SA. Expression of a human growth hormone (hGH) receptor isoform is predicted by tissue-specific alternative splicing of exon 3 of the hGH receptor gene transcript. Molecular Endocrinology 19926 279-287. (doi:10.1210/ mend.6.2.1569971)

8 Mercado M, DáVila N, McLeod JF \& Baumann G. Distribution of growth hormone receptor messenger ribonucleic acid containing and lacking exon 3 in human tissues. Journal of Clinical Endocrinology and Metabolism 199478 731-735. (doi:10.1210/jcem.78.3.8126150)

9 Wickelgren RB, Landin KL, Ohlsson C \& Carlsson LM. Expression of exon 3-retaining and exon 3-excluding isoforms of the human growth hormone-receptor is regulated in an interindividual, rather than a tissue-specific, manner. Journal of Clinical Endocrinology and Metabolism 199580 2154-2157. (doi:10.1210/jcem.80.7.7608270)

10 Zogopoulos G, Figueiredo R, Jenab A, Ali Z, Lefèbvre Y \& Goodyer CG. Expression of exon 3-retaining and -deleted human growth hormone receptor messenger ribonucleic acid isoforms during development. Journal of Clinical Endocrinology and Metabolism 199681 775-782. (doi:10.1210/jcem.81.2.8636303)

11 Stallings-Mann ML, Ludwiczak RL, Klinger KW \& Rottman F. Alternative splicing of exon 3 of the human growth hormone receptor is the result of an unusual genetic polymorphism. PNAS 199693 12394-12399. (doi:10.1073/pnas.93.22.12394)

12 Pantel J, Machinis K, Sobrier ML, Duquesnoy P, Goossens M \& Amselem S. Species-specific alternative splice mimicry at the growth hormone receptor locus revealed by the lineage of retroelements during primate evolution. Journal of Biological Chemistry 2000275 18664-18669. (doi:10.1074/jbc.M001615200)

13 Wan J, Atzmon G, Hwang D, Barzlai N, Kratzsch J \& Cohen P. Growth hormone receptor (GHR) exon 3 polymorphism status detection by dual-enzyme-linked immunosorbent assay (ELISA). Journal of Clinical Endocrinology and Metabolism 201398 E77-E81. (doi:10.1210/jc.2012-2375)

14 Bass SH, Mulkerrin MG \& Wells JA. A systematic mutational analysis of hormone-binding determinants in the human growth 
hormone receptor. PNAS 199188 4498-4502. (doi:10.1073/ pnas.88.10.4498)

15 Urbanek M, Russell JE, Cooke NE \& Liebhaber SA. Functional characterization of the alternatively spliced, placental human growth hormone receptor. Journal of Biological Chemistry 1993268 19025-19032.

16 Clackson T \& Wells JA. A hot spot of binding energy in a hormonereceptor interface. Science 1995267 383-386. (doi:10.1126/ science.7529940)

17 Dos Santos C, Essioux L, Teinturier C, Tauber M, Goffin V \& Bougnères $\mathrm{P}$. A common polymorphism of the growth hormone receptor is associated with increased responsiveness to growth hormone. Nature Genetics 200436 720-724. (doi:10.1038/ng1379)

18 Pantel J, Grulich-Henn J, Bettendorf M, Strasburger CJ, Heinrich U \& Amselem S. Heterozygous nonsense mutation in exon 3 of the growth hormone receptor (GHR) in severe GH insensitivity (Laron syndrome) and the issue of the origin and function of the GHRd3 isoform. Journal of Clinical Endocrinology and Metabolism $2003 \mathbf{8 8}$ 1705-1710. (doi:10.1210/jc.2002-021667)

19 Lettre G, Butler JL, Ardlie KG \& Hirschhorn JN. Common genetic variation in eight genes of the GH/IGF1 axis does not contribute to adult height variation. Human Genetics 2007122 129-139. (doi:10.1007/s00439-007-0385-4)

20 Martins CS, Fernandes-Rosa FL, Espineira AR, de Souza RM, de Castro M, Barbieri MA, Bettiol H, Jorge AL \& Antonini SR. The growth hormone receptor exon 3 polymorphism is not associated with height or metabolic traits in healthy young adults. Growth Hormone and IGF Research 201424 123-129. (doi:10.1016/j. ghir.2014.04.005)

21 Strawbridge RJ, Kärvestedt L, Li C, Efendic S, Ostenson CG, Gu HF \& Brismar K. GHR exon 3 polymorphism: association with type 2 diabetes mellitus and metabolic disorder. Growth Hormone and IGF Research 200717 392-398. (doi:10.1016/j.ghir.2007.04.005)

22 Jensen RB, Vielwerth S, Larsen T, Greisen G, Leffers H \& Juul A. The presence of the d3-growth hormone receptor polymorphism is negatively associated with fetal growth but positively associated with postnatal growth in healthy subjects. Journal of Clinical Endocrinology and Metabolism 200792 2758-2763. (doi:10.1210/jc.2007-0176)

23 Padidela R, Bryan SM, Abu-Amero S, Hudson-Davies RE, Achermann JC, Moore GE \& Hindmarsh PC. The growth hormone receptor gene deleted for exon three (GHRd3) polymorphism is associated with birth and placental weight. Clinical Endocrinology 201276 236-240. (doi:10.1111/j.1365-2265.2011.04207.x)

24 Vincenzi M, Ion Popa F, Corradi M, Gandini A, Teofoli F, Camilot M, Boner A, Cavarzere P, Gaudino R \& Antoniazzi F. Analysis of the d3-growth hormone receptor polymorphism in large cohorts of small, appropriate and large for gestational age newborns. Minerva Pediatrica 201668 157-161.

25 Sørensen K, Aksglaede L, Munch-Andersen T, AachmannAndersen NJ, Leffers H, Helge JW, Hilsted L \& Juul A. Impact of the growth hormone receptor exon 3 deletion gene polymorphism on glucose metabolism, lipids, and insulin-like growth factor-I levels during puberty. Journal of Clinical Endocrinology and Metabolism 2009 94 2966-2969. (doi:10.1210/jc.2009-0313)

26 Sørensen K, Aksglaede L, Petersen JH, Leffers H \& Juul A. The exon 3 deleted growth hormone receptor gene is associated with small birth size and early pubertal onset in healthy boys. Journal of Clinical Endocrinology and Metabolism 201095 2819-2826. (doi:10.1210/ jc.2009-2484)

27 Glad CA, Carlsson LM, Melander O, Almgren P, Sjöström L, Nilsson S, Larsson I, Svensson PA \& Johannsson G. The GH receptor exon 3 deleted/full-length polymorphism is associated with central adiposity in the general population. European Journal of Endocrinology 2015172 123-128. (doi:10.1530/EJE-14-0723)

28 Gao L, Zheng Z, Cao L, Shen S, Yang Y, Zhao Z, Zhi D, Cheng R, Pei Z, Yongfu Y et al. The growth hormone receptor (GHR) exon 3 polymorphism and its correlation with metabolic profiles in obese Chinese children. Pediatric Diabetes 201112 429-434. (doi:10.1111/ j.1399-5448.2010.00747.x)

29 Ben-Avraham D, Govindaraju DR, Budagov T, Fradin D, Durda P, Liu B, Ott S, Gutman D, Sharvit L, Kaplan R et al. The GH receptor exon 3 deletion is a marker of male-specific exceptional longevity associated with increased GH sensitivity and taller stature. Science Advances 20173 e1602025. (doi:10.1126/sciadv.1602025)

30 Wassenaar MJ, Dekkers OM, Pereira AM, Wit JM, Smit JW, Biermasz NR \& Romijn JA. Impact of the exon 3-deleted growth hormone (GH) receptor polymorphism on baseline height and the growth response to recombinant human GH therapy in GH-deficient (GHD) and non-GHD children with short stature: a systematic review and meta-analysis. Journal of Clinical Endocrinology and Metabolism 200994 3721-3730. (doi:10.1210/jc.2009-0425)

31 Renehan AG, Solomon M, Zwahlen M, Morjaria R, Whatmore A, Audí L, Binder G, Blum W, Bougnères $\mathrm{P}$, Santos $\mathrm{CD}$ et al. Growth hormone receptor polymorphism and growth hormone therapy response in children: a Bayesian meta-analysis. American Journal of Epidemiology 2012175 867-877. (doi:10.1093/aje/kwr408)

32 Wei Y, Zheng R, Zhou Y, Wang J \& Bao P. Correlation between exon 3 polymorphism of growth hormone receptor gene and the responses to rhGH therapy. International Journal of Clinical and Experimental Pathology 20158 7371-7377.

33 Zheng Z, Cao L, Pei Z, Zhi D, Zhao Z, Xi L, Cheng R \& Luo F. Relationship between initial treatment effect of recombinant human growth hormone and exon 3 polymorphism of growth hormone receptor in Chinese children with growth hormone deficiency. International Journal of Clinical and Experimental Pathology 20158 7965-7970.

34 Vassiliou G, Rousso I, Katzos G, Vavatsi-Christaki N \& Tzimagiorgis G. Correlation of $\mathrm{fl} / \mathrm{d} 3$ polymorphism of growth hormone receptor with the first- and second-year response to recombinant human growth hormone therapy in pre-pubertal Greek children with idiopathic isolated growth hormone deficiency. Journal of Endocrinological Investigation 201134 609-614. (doi:10.3275/7267)

35 Szmit-Domagalska J, Petriczko E, Drozdzynska M, Adler G, Horodnicka-Jozwa A, Ciechanowicz A \& Walczak M. The impact of the d3-growth hormone receptor (d3-GHR) polymorphism on the therapeutic effect of growth hormone replacement in children with idiopathic growth hormone deficiency in Poland. Neuroendocrinology Letters 201637 282-288.

36 Baş F, Darendeliler F, Aycan Z, Çetinkaya E, Berberoğlu M, Sıklar Z, Öcal G, Timirci Ö, Cetinkaya S, Darcan Ş et al. The exon 3-deleted/ full-length growth hormone receptor polymorphism and response to growth hormone therapy in growth hormone deficiency and Turner syndrome: a multicenter study. Hormone Research in Paediatrics 2012 77 85-93. (doi:10.1159/000335172)

37 Valsesia A, Chatelain P, Stevens A, Peterkova VA, Belgorosky A, Maghnie M, Antoniazzi F, Koledova E, Wojcik J, Farmer P et al. GH deficiency status combined with GH receptor polymorphism affects response to GH in children. European Journal of Endocrinology 2015 173 777-789. (doi:10.1530/EJE-15-0474)

38 Hellgren G, Glad CA, Jonsson B, Johannsson G \& AlbertssonWikland $\mathrm{K}$. The growth hormone receptor exon 3-deleted/fulllength polymorphism and response to growth hormone therapy in prepubertal idiopathic short children. Growth Hormone and IGF Research 201525 127-135. (doi:10.1016/j.ghir.2015.02.003)

39 Dörr HG, Bettendorf M, Hauffa BP, Mehls O, Rohrer T, Stahnke N, Pfäffle R, Ranke MB \& German KIGS Group. Different relationships between the first 2 years on growth hormone treatment and the d3-growth hormone receptor polymorphism in short small-forgestational-age (SGA) children. Clinical Endocrinology 201175 656-660. (doi:10.1111/j.1365-2265.2011.04104.x)

40 Ko JM, Kim JM, Cheon CK, Kim DH, Lee DY, Cheong WY, Kim EY, Park MJ \& Yoo HW. The common exon 3 polymorphism of the 
growth hormone receptor gene and the effect of growth hormone therapy on growth in Korean patients with Turner syndrome. Clinical Endocrinology 201072 196-202. (doi:10.1111/j.13652265.2009.03681.x)

41 Drori-Herishanu L, Lodish M, Verma S, Bimpaki E, Keil MF, Horvath A \& Stratakis CA. The growth hormone receptor (GHR) polymorphism in growth-retarded children with Cushing disease: lack of association with growth and measures of the somatotropic axis. Hormone and Metabolic Research 201042 194-197. (doi:10.105 5/s-0029-1242744)

42 Glad CA, Johannsson G, Carlsson LM \& Svensson PA. Rapid and high throughput genotyping of the growth hormone receptor exon 3 deleted/full-length polymorphism using a tagSNP. Growth Hormone and IGF Research 201020 270-273. (doi:10.1016/j. ghir.2010.02.004)

43 Wit JM, Ranke MB, Albertsson-Wikland K, Carrascosa A, Rosenfeld RG, Van Buuren S, Kristrom B, Schoenau E, Audi L, Hokken-Koelega AC et al. Personalized approach to growth hormone treatment: clinical use of growth prediction models. Hormone Research in Paediatrics 201379 257-270. (doi:10.1159/000351025)

44 Glad CA, Barbosa EJ, Filipsson Nyström H, Carlsson LM, Nilsson S, Nilsson AG, Svensson PA \& Johannsson G. SNPs within the GH-signaling pathway are associated with the early IGF1 response to GH replacement therapy in GHD adults. European Journal of Endocrinology 2013170 101-107. (doi:10.1530/EJE-13-0685)

45 Barbosa EJL, Palming J, Glad CAM, Filipsson H, Koranyi J, Bengtsson BA, Carlsson LMS, Boguszewski CL \& Johannsson G. Influence of the exon 3-deleted/full-length growth hormone (GH) receptor polymorphism on the response to $\mathrm{GH}$ replacement therapy in adults with severe GH deficiency. Journal of Clinical Endocrinology and Metabolism 200994 639-644. (doi:10.1210/jc.2008-0323)

46 Andujar-Plata P, Fernandez-Rodriguez E, Quinteiro C, Casanueva FF $\&$ Bernabeu I. Influence of the exon 3 deletion of GH receptor and IGF-I level at diagnosis on the efficacy and safety of treatment with somatotropin in adults with GH deficiency. Pituitary 201518 101-107. (doi:10.1007/s11102-014-0562-0)

47 Moyes VJ, Walker DM, Owusu-Antwi S, Maher KT, Metherell L, Akker SA, Monson JP, Clark AJL \& Drake WM. d3-GHR genotype does not explain heterogeneity in GH responsiveness in hypopituitary adults. Clinical Endocrinology 201072 807-813. (doi:10.1111/j.13652265.2009.03768.x)

48 Meyer S, Schaefer S, Stolk L, Arp P, Uitterlinden AG, Plöckinger U, Stalla GK, Tuschy U, Weber MM, Weise A et al. Association of the exon 3 deleted/full-length GHR polymorphism with recombinant growth hormone dose in growth hormone-deficient adults. Pharmacogenomics 200910 1599-1608. (doi:10.2217/pgs.09.91)

49 Adetunji OR, Blair JC, Javadpour M, Alfirevic A, Pirmohamed M \& MacFarlane IA. Deletion of exon 3 in the growth hormone receptor gene in adults with growth hormone deficiency: comparison of symptomatic and asymptomatic patients. Clinical Endocrinology 2010 72 422-426. (doi:10.1111/j.1365-2265.2009.03638.x)

50 Adetunji OR, MacFarlane IA, Javadpour M, Alfirevic A, Pirmohamed M \& Blair JC. The d3/fl-GH receptor gene polymorphism does not influence quality of life and body composition in GH-deficient adults receiving GH replacement therapy. European Journal of Endocrinology 2009161 541-546. (doi:10.1530/EJE-09-0405)

51 van der Klaauw AA, van der Straaten T, Baak-Pablo R, Biermasz NR, Guchelaar HJ, Pereira AM, Smit JW \& Romijn JA. Influence of the d3-growth hormone (GH) receptor isoform on short-term and longterm treatment response to GH replacement in GH-deficient adults. Journal of Clinical Endocrinology and Metabolism 200893 2828-2834. (doi:10.1210/jc.2007-2728)

52 Giavoli C, Ferrante E, Profka E, Olgiati L, Bergamaschi S, Ronchi CL, Verrua E, Filopanti M, Passeri E, Montefusco L et al. Influence of the d3GH receptor polymorphism on the metabolic and biochemical phenotype of GH-deficient adults at baseline and during short- and long-term recombinant human GH replacement therapy. European Journal of Endocrinology 2010163 361-368. (doi:10.1530/EJE-100317)

53 Abreu A, Tovar AP, Castellanos R, Valenzuela A, Giraldo CM, Pinedo AC, Guerrero DP, Barrera CA, Franco HI, Ribeiro-Oliveira A et al. Challenges in the diagnosis and management of acromegaly: a focus on comorbidities. Pituitary 201619 448-457. (doi:10.1007/ s11102-016-0725-2)

54 Lesén E, Granfeldt D, Houchard A, Dinet J, Berthon A, Olsson DS, Björholt I \& Johannsson G. Comorbidities, treatment patterns and cost-of-illness of acromegaly in Sweden: a register-linkage population-based study. European Journal of Endocrinology 2017176 203-212. (doi:10.1530/EJE-16-0623)

55 de Oliveira Machado E, Lima CH, Ogino LL, Kasuki L \& Gadelha MR. Growth hormone receptor exon 3 isoforms may have no importance in the clinical setting of multiethnic Brazilian acromegaly patients. Pituitary 201619 375-380. (doi:10.1007/ s11102-016-0715-4)

56 Schmid C, Krayenbuehl PA, Bernays RL, Zwimpfer C, Maly FE \& Wiesli P. Growth hormone (GH) receptor isoform in acromegaly: lower concentrations of GH but not insulin-like growth factor-1 in patients with a genomic deletion of exon 3 in the GH receptor gene. Clinical Chemistry 200753 1484-1488. (doi:10.1373/ clinchem.2007.085712)

57 Mercado M, González B, Sandoval C, Esquenazi Y, Mier F, Vargas G, de los Monteros AL \& Sosa E. Clinical and biochemical impact of the $\mathrm{d} 3$ growth hormone receptor genotype in acromegaly. Journal of Clinical Endocrinology and Metabolism 200893 3411-3415. (doi:10.1210/jc.2008-0391)

58 Bianchi A, Mazziotti G, Tilaro L, Cimino V, Veltri F, Gaetani E, Pecorini G, Pontecorvi A, Giustina A \& De Marinis L. Growth hormone receptor polymorphism and the effects of pegvisomant in acromegaly. Pituitary 200912 196-199. (doi:10.1007/s11102-0080157-8)

59 Bianchi A, Giustina A, Cimino V, Pola R, Angelini F, Pontecorvi A \& De Marinis L. Influence of growth hormone receptor $\mathrm{d} 3$ and fulllength isoforms on biochemical treatment outcomes in acromegaly. Journal of Clinical Endocrinology and Metabolism 200994 2015-2022. (doi:10.1210/jc.2008-1337)

60 Wassenaar MJ, Biermasz NR, Pereira AM, van der Klaauw AA, Smit JW, Roelfsema F, van der Straaten T, Cazemier M, Hommes DW, Kroon HM et al. The exon-3 deleted growth hormone receptor polymorphism predisposes to long-term complications of acromegaly. Journal of Clinical Endocrinology and Metabolism 200994 4671-4678. (doi:10.1210/jc.2009-1172)

61 Kamenicky P, Dos Santos C, Espinosa C, Salenave S, Galland F, Le Bouc Y, Maison P, Bougnères P \& Chanson P. D3 GH receptor polymorphism is not associated with IGF1 levels in untreated acromegaly. European Journal of Endocrinology 2009161 231-235. (doi:10.1530/EJE-09-0053)

62 Bernabeu I, Alvarez-Escolá C, Quinteiro C, Lucas T, Puig-Domingo M, Luque-Ramírez M, de Miguel-Novoa P, Fernandez-Rodriguez E, Halperin I, Loidi L et al. The exon 3-deleted growth hormone receptor is associated with better response to pegvisomant therapy in acromegaly. Journal of Clinical Endocrinology and Metabolism 201095 222-229. (doi:10.1210/jc.2009-1630)

63 Montefusco L, Filopanti M, Ronchi CL, Olgiati L, La-Porta C, Losa M, Epaminonda P, Coletti F, Beck-Peccoz P, Spada A et al. d3-growth hormone receptor polymorphism in acromegaly: effects on metabolic phenotype. Clinical Endocrinology 201072 661-667. (doi:10.1111/j.1365-2265.2009.03703.x)

64 Turgut S, Akın F, Ayada C, Topsakal S, Yerlikaya E \& Turgut G. The growth hormone receptor polymorphism in patients with acromegaly: relationship to BMI and glucose metabolism. Pituitary 201215 374-379. (doi:10.1007/s11102-011-0329-9) 
65 Filopanti M, Olgiati L, Mantovani G, Corbetta S, Arosio M, Gasco V, De Marinis L, Martini C, Bogazzi F, Cannavò S et al. Growth hormone receptor variants and response to pegvisomant in monotherapy or in combination with somatostatin analogs in acromegalic patients: a multicenter study. Journal of Clinical Endocrinology and Metabolism 201297 E165-E172. (doi:10.1210/jc.2011-1769)

66 Kohler S, Tschopp O, Sze L, Neidert M, Bernays RL, Spanaus KS, Wiesli P \& Schmid C. Monitoring for potential residual disease activity by serum insulin-like growth factor 1 and soluble Klotho in patients with acromegaly after pituitary surgery: is there an impact of the genomic deletion of exon 3 in the growth hormone receptor (d3-GHR) gene on 'safe' GH cut-off values? General and Comparative Endocrinology 2013188 282-287. (doi:10.1016/j. ygcen.2013.04.024)

67 Mormando M, Nasto LA, Bianchi A, Mazziotti G, Giampietro A, Pola E, Pontecorvi A, Giustina A \& De Marinis L. GH receptor isoforms and skeletal fragility in acromegaly. European Journal of Endocrinology 2014171 237-245. (doi:10.1530/EJE-14-0205)

68 Jallad RS, Trarbach EB, Duarte FH, Jorge AA \& Bronstein MD. Influence of growth hormone receptor (GHR) exon 3 and -202A/C IGFBP-3 genetic polymorphisms on clinical and biochemical features and therapeutic outcome of patients with acromegaly. Pituitary 2015 18 666-673. (doi:10.1007/s11102-014-0629-y)

69 Cinar N, Dagdelen S, Yorgun H, Canpolat U, Kabakçı G \& Erbas T. The clinical and cardiometabolic effects of d3-growth hormone receptor polymorphism in acromegaly. Pituitary 201518 116-125. (doi:10.1007/s11102-014-0564-y)

70 Franck SE, van der Lely AJ, Delhanty PJ, Jørgensen JO \& Neggers SJ. Pegvisomant in combination with long-acting somatostatin analogues in acromegaly: the role of the GH receptor deletion of exon 3. European Journal of Endocrinology 2015173 553-561. (doi:10.1530/EJE-15-0519)

71 Park HY, Hwang IR, Seo JB, Kim SW, Seo HA, Lee IK \& Kim JG. Association between the growth hormone receptor exon 3 polymorphism and metabolic factors in korean patients with acromegaly. Endocrinology and Metabolism 201530 312-317. (doi:10.3803/EnM.2015.30.3.312)

72 Franck SE, Broer L, van der Lely AJ, Kamenicky P, Bernabéu I, Malchiodi E, Delhanty PJ, Rivadeneira F \& Neggers SJ. The effect of the exon-3-deleted GH-receptor in pegvisomant-treated acromegaly: a systematic review and meta-analysis. Neuroendocrinology 2016105 131-140. (Epub ahead of print) (doi:10.1159/000448844)

73 Park SW, Lee ST, Sohn YB, Kim SH, Cho SY, Ko AR, Ji ST, Kwon JY, Yeau S, Paik KH et al. A polymorphism in the growth hormone receptor is associated with height in children with Prader-Willi syndrome. American Journal of Medical Genetics Part A 2011 155A 2970-2973. (doi:10.1002/ajmg.a.34309)

74 Butler MG, Roberts J, Hayes J, Tan X \& Manzardo AM. Growth hormone receptor (GHR) gene polymorphism and Prader-Willi syndrome. American Journal of Medical Genetics Part A 2013 161A 1647-1653. (doi:10.1002/ajmg.a.35980)

75 Shen Y, Wang L, Zhao Y, You L, Geng L, Gu HF \& Chen ZJ. Evaluation of the association between GHR exon 3 polymorphism and polycystic ovary syndrome among Han Chinese women. Growth Hormone and IGF Research 201121 248-251. (doi:10.1016/j. ghir.2011.07.002)

76 Claessen KM, Kloppenburg M, Kroon HM, Bijsterbosch J, Pereira AM, Romijn JA, van der Straaten T, Nelissen RG, Hofman A, Uitterlinden AG et al. Relationship between the functional exon 3 deleted growth hormone receptor polymorphism and symptomatic osteoarthritis in women. Annals of the Rheumatic Diseases 201473 433-436. (doi:10.1136/annrheumdis-2012-202713)

77 Kucukhuseyin O, Toptas B, Timirci-Kahraman O, Isbir S, Karsidag K \& Isbir T. The effect of GHR/exon-3 polymorphism and serum GH, IGF-1 and IGFBP-3 levels in diabetes and coronary heart disease. In Vivo 201529 371-378.

$78 \mathrm{Gu}$ HF, Efendic S \& Brismar K. Lack of an association between GHR exon 3 polymorphism and diabetic nephropathy in the Genetics of Kidneys in Diabetes (GoKinD) population. Diabetologia 200851 2333-2334. (doi:10.1007/s00125-008-1145-2)

Received 5 July 2017

Revised version received 7 September 2017

Accepted 12 September 2017 